УДК $347.45 / .47$

DOI https://doi.org/10.32849/2663-5313/2021.3.07

\title{
Ганна Крушельницька,
}

канд. юрид. наук,

старший викладач кафедри цивільно-правових дисциплін

Національної академії внутрішніх справ

\section{ЦИВІЛЬНО-ПРАВОВІ АСПЕКТИ ДОНАЦЇ ЕМБРІОНІВ ЛЮДИНИ IN VITRO}

У статті досліджуються цивільно-правові аспекти донацї ембріонів, з’ясовується зміст поняття донації та його співвідношення з поняттям донорства. Визначається, що з точки зору иивілістики доначія ембріонів іп vitro є правочином, спрямованим на припинення права власності донорів на належні їм ембріони та виникнення права власності на них у інших суб'єктів у сфері штучної репродукиіі. Зазначається, що предметом доначї ембріонів можуть бути тільки кріоконсервовані ембріони, незалежно від наявності чи відсутності генетичного зв'язку з донорами. На підставі комплексного аналізу положень законодавства встановлюються сторони правочину донації ембріонів. Зокрема, визначається, що обов'язковим суб'єктом донаиї є донор. У зв'язку з иим досліджується, які особи можуть бути донорами ембріонів. Надається розуміння поняття «пацієнти програми запліднення іп vitro». Аналізуються умови, за яких паиієнти, шо проходили лікування методами допоміжних репродуктивних технологій, можуть надавати згоду на донорство ембріонів. Залежно від виду доначії (анонімна чи неанонімна) автором визначається друга сторона досліджуваного правочину заклад охорони здоров'я у разі анонімного донорства та безпосереднъо реципієнти у разі неанонімного адресного донорства. У статті також розглядається можливість відкликання добровільної інформованої згоди на донацію ембріонів, у результаті чого автор доходить висновку, що таке відкликання до моменту імплантаиї ембріонів не суперечить чинному законодавству Украйни, при иьому пропонується зобов'язувати донорів відикодувати іншій стороні витрати на зберігання донорських ембріонів у кріобанку. Крім того, досліджуються особливості посмертної доначї̈ ембріонів іп vitro, якщо їхніми власниками не було зроблено відповідного розпорядження на випадок смерті. Зокрема, автор робить висновок, що можливість розпорядитися кріоконсервованими ембріонами після смерті пацієнтів, яким вони належали, залежить від наявності чи відсутності генетичного зв'язку з ними. Також у статті аналізується можливість виплати донорам ембріонів грошової компенсації з огляду на правову природу донаиіі.

Ключові слова: допоміжні репродуктивні технології, ембріони in vitro, біоматеріали, донорство, донори репродуктивних клітин.

Постановка проблеми. Інтенсивний розвиток біомедицинських технологій у сфері штучної репродукції вимагає розробки чіткої нормативної бази для їх застосування. Незважаючи на це, в Україні досі відсутне належне правове регулювання у вказаній сфері: вітчизняне законодавство практично не містить норм, які б закріплювали особливості донації ембріонів людини in vitro. Актуальність теми статті зумовлюється також тим, що Концепцією щодо основних напрямів системного оновлення Цивільного кодексу України, підготовленою членами Робочої групи, утвореної постановою Кабінету Міністрів України «Про утворення робочої групи щодо рекодифікації (оновлення) цивільного законодавства України» від 17 липня 2019 р. № 650, передбачається об'єктивація репродуктивних прав фізичної особи у тому числі шляхом визначення умов та порядку застосування допоміжних репро- дуктивних технологій спеціальним законом. Одним із важливих аспектів, який належить врегулювати, є, зокрема, донація ембріонів in vitro як один зі способів лікування безпліддя, оскільки чинне законодавство містить значну кількість прогалин та колізій у цій сфері.

Аналіз останніх досліджень і публікацій. Питання цивілістичної природи донації ембріонів in vitro $є$ малодослідженим, водночас останнім часом з'являються наукові роботи, у яких розглядаються різні аспекти цього правового явища як у розрізі цивільноправового регулювання права на репродукцію, так і в контексті права на донорство. Серед них слід відзначити теоретичні доробки Ю. Ф. Дружиніної, А. С. Шабанової, А. П. Головащук, В. І. Чечерського, К. О. Ільющенкової та інших. Значно більше уваги донації ембріонів приділяється зарубіжними вченими, зокрема, вказане питання 
досліджували J. A. Robertson, M. Kaminsky, S. Ahmed, J. R. Hoffman, Ch. P. Kindregan, M. McBrien, K. A. Moore, C. Westbrook та інші.

Постановка завдання. Метою статті є дослідження цивільно-правових аспектів донації ембріонів людини in vitro, зокрема iї поняття, предмета, суб'єктного складу, можливості відкликання згоди на донорство ембріонів, а також можливості встановлення грошової компенсації донорам.

Виклад основного матеріалу. Порядком застосування допоміжних репродуктивних технологій в Україні, затвердженим наказом Міністерства охорони здоров'я України від 09.09.2013 року № 787 (далі - Порядок застосування ДРТ), передбачено можливість донації ембріонів. Зокрема, у п. 5.1 цього Порядку донація ембріонів визначається як процедура, за якою донори за письмово оформленою добровільною згодою надають свої ембріони для використання в інших осіб для лікування безпліддя. При цьому у додатку 11 до Порядку застосування ДРТ міститься форма «інформованої добровільної згоди на донорство ембріонів». Отже, видається, шо законодавець ототожнює поняття «донація ембріонів» та «донорство ембріонів». Така позиція характерна і для інших нормативно-правових актів: зокрема, у Законі України «Про безпеку та якість донорської крові та компонентів крові» донорство визначається як «здійснення донором донації». Так само у Законі України «Про донорство крові та її компонентів», що втратив чинність 25.01.2021 року, донорство визначалося як «добровільний акт волевиявлення людини, що полягає у даванні». Тобто законодавець, формулюючи нове визначення поняття «донорство крові та компонентів крові», замінив слово «давання» на «донація». У свою чергу, в Директиві Европейського Парламенту і Ради 2004/23/ЄС від 31 березня 2004 року про встановлення стандартів якості та безпечності для донації, заготівлі, тестування, перероблення, консервації, зберігання та реалізації людських тканин і клітин «донація» визначається як «надання людських тканин чи клітин, призначених для застосування на людях».

Що стосується доктринальної точки зору, то К. В. Гребенникова визначає донорство як добровільне надання органів та клітин донора для їх використання іншою особою [1, с. 210]. На думку I. Р. Пташник, донорство є соціально корисною, заснованою на вільному волевиявленні діяльністю громадянина (донора), яка полягає в безоплатному наданні крові, органів та тканин медичній установі для лікування реципієнта, з наступним наданням донору матеріальних та інших пільг [2, с. 56]. М. С. Брюховецька вказує, що донорство означає добровільний акт волевиявлення людини, що полягає у наданні крові та її компонентів, а також органів або інших тканин $з$ метою лікування хворого, тому, виходячи із зазначеного, донорством є добровільна дія людини, спрямована на передачу свого анатомічного матеріалу іншій особі [3, с. 73]. Таким чином, і донація, і донорство означають надання певного біоматеріалу для використання іншими особами, тому ці поняття є синонімічними і до донації ембріонів можуть застосовуватися загальні положення про донорство.

Із позиції цивільного права донацію ембріонів доцільно розглядати як правочин, оскільки добровільне надання донорами своїх ембріонів для використання в інших осіб у лікуванні безпліддя можна віднести до юридичних актів суб'єктів приватного права, спеціально спрямованих на встановлення, зміну або припинення правовідносин. Зокрема, донація ембріонів є способом реалізації правомочності розпорядження ембріонами in vitro шляхом вчинення донорами вольової дії, спрямованої на припинення права власності на належні їм ембріони in vitro у результаті відчуження на користь інших осіб.

Враховуючи складний морально-етичний аспект правового статусу ембріонів людини in vitro, зокрема віднесення їх до особливих об'єктів цивільних прав, свідомо чи ні, але у Порядку застосування ДРТ законодавець називає донацію ембріонів не правочином, а саме процедурою. При цьому з юридичної точки зору, як вказує О. В. Члевик, під процедурою слід розуміти певний порядок вчинення дій, який спрямований на реалізацію відповідного правовідношення [4, с. 69]. Більш розширено юридичну процедуру визначає О. П. Євсєєв, розуміючи її як нормативно або індивідуально встановлений порядок послідовного здійснення уповноваженими суб'єктами права узгоджених юридичних дій, спрямованих на досягнення загального для них правового результату [5, с. 20].

Водночас, визначаючи донацію ембріонів як процедуру, законодавець такої процедури якраз і не встановлює, оскільки ні Порядок застосування ДРТ, ні інші нормативно-правові акти не містять належного правового регулювання донації ембріонів, допускаючи вільне тлумачення можливостей реалізації такої юридичної дії. Саме тому в цій статті будуть розглядатися окремі цивільно-правові аспекти донації ембріонів in vitro. 
Так, одним із важливих питань, що потребують дослідження в контексті розуміння донації ембріонів як цивільного правочину, $€$ визначення його предмета. Говорячи про предмет правочину, автор дотримується позиції, висловленої М. М. Агарковим, який розглядає предмет правочину як певне благо (майно), з приводу якого вчиняється правочин [6, с. 205].

Комплексний аналіз положень Порядку застосування ДРТ дозволяе дійти висновку, що предметом донації ембріонів можуть бути саме кріоконсервовані ембріони. Про це свідчить вказівка на необхідність наявності в донорів у кріобанку невикористаних кріоконсервованих ембріонів. У пункті 3.8 вказаного Порядку встановлено, що перенесення ембріонів до порожнини матки може здійснюватися на стадіях, починаючи зі стадії зиготи і закінчуючи стадією бластоцисти, яка формується у людини на 5-6-й день після запліднення. Тому ембріони in vitro можуть бути кріоконсервованими на будь-якій із цих стадій, аби після розморожування залишатися придатними для імплантації в організм жінки. Як видно із п. 5.1 Порядку застосування ДРТ, на цій стадії донація свіжих біологічно активних ембріонів неможлива.

Оскільки у разі донації йдеться саме про кріоконсервовані ембріони, варто відзначити, що для заморожування ембріони поміщають у рідкий азот дуже низьких температур при яких припиняється будь-яка біологічна активність, проте життєдіяльна активність зберігається неушкодженою [7, с. 45]. Положення пунктів 11.1-11.3 Порядку застосування ДРТ в Україні вказують на визначення законодавцем кріоконсервованих ембріонів in vitro як біологічного матеріалу пацієнта/ пацієнтів. Таким чином, під кріоконсервованими ембріонами людини in vitro як предметом донації належить розуміти біоматеріал, а саме створений у спеціальному лабораторному посуді або у контрольованому середовищі поза живим організмом біологічно неактивний ембріон на стадії від зиготи до бластоцисти, що зберігається у рідкому азоті наднизьких температур та не перебуває у стані розвитку.

Оскільки донація ембріонів - це один зі способів визначення подальшої долі невикористаних у лікуванні методами ДРТ кріоембріонів, що є одночасно підставою припинення права власності на них у одного суб'єкта (відчужувача) та підставою виникнення права власності в іншого (набувача), видається, що не має значення наявність чи відсутність генетичного зв'язку донорів з ембріонами, що донуються. У разі запліднення донорських ооцитів спермою донора право власності на ембріони у порядку специфікації набувають пацієнти програми запліднення in vitro, а не заклад охорони здоров'я, що надає відповідні медичні послуги. Тому ембріони, утворені повністю із донорських репродуктивних клітин, можуть відчужуватися у порядку донації на таких самих умовах, як і ембріони, що генетично пов'язані з донорами.

Друге питання, яке потребує з'ясування в контексті дослідження донації ембріонів, це особи, які можуть бути сторонами такої донації. Зокрема, у відносинах донорства до них прийнято відносити донора, заклад охорони здоров’я та реципієнта, хоча останній не завжди може бути стороною безпосередньо у правочині донації ембріонів.

Так, у п. 5.21 Порядку застосування ДРТ вказано, що донорами ембріонів можуть бути пацієнти програми запліднення in vitro, у яких після народження дитини залишаються у кріобанку невикористані кріоконсервовані ембріони.

Тобто першою умовою, за якої особи можуть бути донорами ембріонів, є наявність статусу пацієнта програми запліднення in vitro, тому спершу необхідно встановити, кого слід відносити до таких пацієнтів. Видається, що пацієнтами програми запліднення in vitro можуть бути незалежно від громадянства одинокі повнолітні чоловік або жінка, подружжя, жінка та чоловік, які не перебувають у зареєстрованому шлюбі, але бажають мати спільну дитину, які мають медичні показання (чоловіче або жіноче безпліддя), не мають визначених законом протипоказань до проведення лікувальних програм ДРТ шляхом запліднення in vitro та уклали договір із закладом охорони здоров'я про надання відповідних медичних послуг.

Другою умовою для донації ембріонів $€$ факт народження у пацієнтів програми запліднення in vitro дитини у результаті застосування до них ДРТ, який, вочевидь, підтверджується свідоцтвом про народження дитини. Водночас у п. 3.12 Порядку застосування ДРТ зазначається, що після завершення циклу запліднення, за наявності залишку невикористаних ембріонів, пацієнтка може прийняти рішення про використання цих ембріонів для лікувальних програм інших пацієнтів. При цьому згідно з п. 3.3 цього ж Порядку, де визначено етапність проведення запліднення in vitro, цикл запліднення завершується діагностикою вагітності. Очевидно, що рішення про використання ембріонів для лікування безпліддя в інших пацієнтів повинно реалізуватися безпосередньо шляхом донації ембріонів, яка, у свою чергу, можлива лише після народження дитини, а не після діагностики вагіт- 
ності. У такому випадку виникає питання: яке правове значення буде мати зазначене рішення «пацієнтки», у якої діагностували вагітність у результаті застосування ДРТ, і чому йдеться лише про волевиявлення жінки, а не спільне рішення, якщо пацієнтами $€$ пара (чоловік і жінка)? Якщо використання у п. 3.12 Порядку застосування ДРТ терміна «пацієнтка» схоже на техніко-юридичну помилку, то можливість прийняття рішення про використання ембріонів для лікування інших пацієнтів на етапі завершення циклу запліднення in vitro можна розглядати як правочин, щодо якого правові наслідки (відчуження ембріонів in vitro шляхом донації) пов'язуються з настанням певної обставини, зокрема народженням дитини. Проте вигода від необхідності висловлення волевиявлення щодо розпорядження невикористаними ембріонами до можливості фактичного вчинення донації ембріонів не зрозуміла, якщо тільки сторони не домовляться, що обов'язок оплачувати зберігання ембріонів у кріобанку покладається на майбутнього набувача права власності на них.

Третьою умовою донорства ембріонів $€$ наявність у пацієнтів у кріобанку невикористаних кріоконсервованих ембріонів, оскільки заморожування надлишкових ембріонів не є обов'язком закладу охорони здоров'я, який надає медичні послуги із застосуванням ДРТ. Відповідно до п. 7.1 Порядку застосування ДРТ кріоконсервація (заморожування і зберігання) ембріонів здійснюється за відповідною заявою пацієнтів програм запліднення in vitro і оплачується ними.

Друга сторона у правочині донації ембріонів in vitro залежить від виду донації. Аналіз положень Порядку застосування ДРТ дозволяє дійти висновку, що донація ембріонів може бути як анонімною, так і неанонімною. У формі інформованої добровільної згоди на донорство ембріонів, затвердженій Міністерством охорони здоров'я України у додатку 11 до Порядку застосування ДРТ, зазначено, що донори зобов'язуються не встановлювати особу пацієнта (реципієнта), а також дитини, що народилась у результаті використання їхніх ембріонів під час проведення методів допоміжної репродукції (у разі анонімного донорства). Отже, законодавець допускає, що донорство ембріонів може бути неанонімним. Зокрема, донори гамет та ембріонів можуть бути відомі реципієнтам за умови родинного споріднення чи неанонімності (давнє знайомство чи інші причини) донора [8, с. 55].

Як вказує К. О. Ільющенкова, критерій анонімності чи неанонімності донора є визначальним для встановлення суб'єктного складу правовідносин донорства [8, с. 56]. Тобто у разі відкритої донації досить укласти договір між донором та реципієнтом, а третій суб'єкт договору - заклад охорони здоров'я - виконує лише посередницьку функцію у здійсненні права на донорство (суб'єкт - донор) та права на медичну допомогу (суб'єкт - реципієнт) [8, с. 168].

Таким чином, у разі анонімної донації ембріонів другою стороною правочину $€$ заклад охорони здоров'я, який, власне, і набуває права власності на ембріони in vitro, оскільки, як правильно відзначає А. С. Шабанова, репродуктивне донорство являє собою акт розпорядження біологічним матеріалом 3 передачею права власності на нього медичній установі [9, с. 84]. Згідно з п. 5.22 Порядку застосування ДРТ ембріони, передані закладу охорони здоров'я у порядку донації, можуть бути використані для лікування безпліддя у пацієнтки/подружньої пари-реципієнта, а також жінкам-реципієнтам, які не перебувають у шлюбі.

Що стосується реципієнтів, то вони можуть бути стороною правочину донації ембріонів у разі неанонімного адресного донорства. Очевидно, що реципієнтами можуть бути лише пацієнти програм запліднення in vitro, тому передумовою укладення правочину донації ембріонів має бути укладення договору із закладом охорони здоров’я про надання медичних послуг із застосуванням ДРТ. У разі укладення правочину неанонімної адресної донації право власності на ембріони in vitro переходить безпосередньо до реципієнтів. У разі ж використання реципієнтами у процесі лікування безпліддя методами ДРТ донорських ембріонів анонімних донорів вони набувають право власності на донорські ембріони in vitro за договором про надання медичних послуг із закладом охорони здоров'я. Для подальшого використання реципієнтами донорських ембріонів законодавець встановлює певні умови, зокрема, до них належать медичні показання, наявність письмової інформованої добровільної згоди пацієнтів, забезпечення анонімності донора та збереження лікарської таємниці.

Наступним аспектом, який є важливою умовою донації ембріонів in vitro, $€$ наявність вільного волевиявлення донорів. Відповідно до Порядку застосування ДРТ таке волевиявлення має бути добровільним, усвідомленим, вираженим у вигляді письмової «інформованої добровільної згоди на донорство ембріонів», форма якої затверджена у Додатку 11 до зазначеного Порядку. Якщо донорами є подружжя або чоловік і жінка, що не перебувають у зареєстрованому шлюбі, 
то згода на донорство має бути спільною, оскільки ембріони in vitro, створені у зв'язку із застосуванням до них програми ДРТ, перебувають у спільній сумісній власності таких пацієнтів. Якщо ж взаємної згоди не буде досягнуто, то питання розпорядження ембріонами шляхом донації буде вирішуватися у судовому порядку.

Однак неврегульованими залишаються питання можливості відкликання згоди на донорство ембріонів, а також посмертне донорство ембріонів in vitro.

Так, вітчизняне законодавство не містить жодних вказівок щодо відкликання згоди на донацію ембріонів, якщо донори змінять своє рішення. Водночас, оскільки кріоконсервовані ембріони законодавець відносить до біологічного матеріалу, до відносин донації ембріонів доцільно застосовувати положення Порядку надання письмової згоди живого донора на вилучення у нього анатомічних матеріалів та письмової відмови від раніше наданої такої згоди, письмової згоди або незгоди чи відкликання наданої раніше згоди на вилучення анатомічних матеріалів з тіла особи для трансплантації та/або виготовлення біоімплантатів після визначення їі стану як незворотня смерть, а також подання письмової заяви про призначення, зміну чи відкликання повноважного представника затвердженого постановою Кабінету Міністрів України від 27 грудня 2018 р. № 1211. Зокрема, у п. 3 вказаного порядку визначено, що кожна повнолітня дієздатна фізична особа має право у будь-який час подати письмову заяву про відмову від раніше наданої згоди живого донора на донорство анатомічних матеріалів. Враховуючи специфіку донації ембріонів, очевидно, що відкликання згоди на донорство можливе тільки до моменту імплантації в організм жінки-реципієнта. При цьому видається, що донор, який відкликав згоду на донорство ембріонів, зобов'язаний відшкодувати закладу охорони здоров'я або безпосередньо реципієнтам (у разі неанонімного адресного донорства) витрати, пов'язані зі зберіганням кріоконсервованих ембріонів у кріобанку з моменту подання донором згоди на донацію.

Що стосується посмертного донорства ембріонів, якщо донор за життя не зробив відповідного застереження у договорі про надання медичних послуг із застосуванням ДРТ, то Ю. Ф. Дружиніна вважає, що у випадку одночасної смерті обох батьків або смерті особи, яка одноосібно володіла ембріонами in vitro, права на них повинні перейти до медичної установи з метою подальшої донації. Таку позицію науковець обгрунтовує міркуваннями суспільної користі, адже суспільство зацікавлене у народженні дітей [10, с. 140]. Підтримує такий підхід i А. П. Головащук, на думку якої знищувати такі ембріони недоцільно і краще передати їх іншій парі пацієнтів програми запліднення in vitro за умови відсутності заперечень з боку родичів загиблого подружжя [11, с. 194]. Із таким підходом не погоджується В. I. Чечерський, зазначаючи, що у такому разі має місце розпорядження ембріонами поза безпосередньою волею їх генетичних батьків та примусова донація поза законодавчими межами, тому ембріони померлих пацієнтів не можуть бути передані іншим особам, подаровані, продані чи іншим чином відчужені. Тому, на думку В. I. Чечерського, за таких обставин єдиним шляхом залишається зберігання гамет чи ембріонів до закінчення встановленого законодавством або договором терміну та подальше їх знищення у встановленому порядку, за винятком випадків з метою продовження власного роду [12, с. 163].

Видається, що у разі смерті пацієнтів програми ДРТ право власності на належні їм ембріони, зокрема і правомочність розпоряджатися ними шляхом донації, може переходити до спадкоємців, проте можливість включення ембріонів in vitro до складу спадщини повинна залежати від наявності генетичного зв'язку зі спадкодавцем. Якщо такий генетичний зв'язок $є$, то варто погодитися 3 позицією Є. Ю. Петрова, який визначає розпорядження щодо ембріона як розпорядження немайнового характеру, що підлягають включенню до заповіту як modus [13]. Інакше права на ембріони in vitro не будуть входити до складу спадщини як такі, що пов'язані з особистими немайновими репродуктивними правами спадкодавця, тому їх донація без прижиттєвої згоди донора $є$ неможливою. У разі відсутності генетичного зв'язку ембріонів in vitro з донором (якщо ембріон було утворено виключно iз донорських репродуктивних клітин) видається, що спадкоємці мають право прийняти рішення про донацію таких ембріонів, оскільки у цьому разі ніяким чином не зачіпаються репродуктивні права донора.

Ще одним питанням, яке доцільно розглянути у межах цієї статті, є можливість встановлення грошової компенсації при донації ембріонів in vitro. Так, за загальним правилом, відповідно до ч. 1 ст. 20 Закону України «Про застосування трансплантації анатомічних матеріалів людині» укладання або пропонування укладення договорів, що передбачають купівлю-продаж анатомічних матеріалів людини, забороняється. При цьому, як уже зазначалося, кріоконсервовані ембріони людини in vitro $є$ біологічним 
(анатомічним) матеріалом, тому вказана заборона іх також стосується. Водночас, згідно з Директивою 2004/23 СС Європейського Парламенту і Ради від 31 листопада 2004 року про встановлення стандартів якості та безпеки при донації, підготовці, випробуванні, обробці, консервації, зберіганні та реалізації тканин та клітин людини, донори можуть отримати компенсацію, суворо обмежену відшкодуванням витрат та незручностей, спричинених донацією. У цьому випадку держави-члени встановлюють умови надання компенсацій. Оскільки, як слушно зауважує Є. Герасименко, для держав, які прагнуть приєднатися до Європейського Союзу, зокрема для України, одним із головних завдань $є$ гармонізація національного законодавства 3 європейськими стандартами. Підписавши та ратифікувавши Угоду про асоціацію між Україною, з однієї сторони, та Європейським Союзом, Свропейським співтовариством з атомної енергії та їхніми державами-членами, з іншої сторони, від 27 червня 2014 року, Україна взяла на себе зобов'язання адаптувати національне законодавство до стандартів Європейського Союзу [14]. Проте вітчизняне законодавство не регулює можливість отримання донорами компенсації за донацію гамет і ембріонів. Для багатьох людей плата донорам за ембріони $є$ неетичною, адже може перетворити іх на товар, що є не припустимим 3 огляду на потенціал розвитку в людину. Водночас, як зазначає M. Камінськи (Michelle Kaminsky), реципієнти, які використовують донорські заморожені ембріони, витрачають набагато менше на лікування за програмою запліднення in vitro, ніж обійшлося би повне лікування із застосуванням методів ДРТ [15]. У свою чергу Дж. Робертсон (John A. Robertson) допускає, що може бути дозволена оплата витрат, пов'язаних з донорством, оскільки донорські ембріони будуть доступні для використання безплідними реципієнтами, оскільки інша безплідна пара надавала свої гамети, необхідні для їх створення, і піддавалася фізичним ризикам та оплачувала значну суму при створенні донорських ембріонів. Саме тому витрати на донорство включають у себе вартість створення ембріонів, отже, певна частина цих витрат повинна бути відшкодована реципієнтами. Проте такий підхід має багато противників, які стверджують, що, оскільки вказані витрати вже були понесені, вони не належать до витрат на донацію, отже, не повинні відшкодовуватися донорам [16, с. 890]. Видається, що останній підхід є більш вдалим, адже на відміну від донації гамет, яку заклади охорони здоров'я можуть стимулювати та заохо- чувати можливістю грошової компенсації, донація ембріонів in vitro не повинна отримувати такого фінансового стимулу. Крім того, правова природа донації ембріонів близька до пожертви, для якої оплатність $€$ недопустимою.

\section{Висновки}

На підставі вищевикладеного можна дійти висновку, що з цивільно-правової точки зору донація ембріонів in vitro $є$ правочином, зокрема вольовою дією суб'єктів цивільних прав, що полягає у наданні письмової згоди на використання належних їм ембріонів для лікування інших пацієнтів програм запліднення in vitro, у результаті чого реалізується правомочність розпорядження ембріонами in vitro, спрямована на припинення права власності на них шляхом відчуження на користь інших осіб. Предметом донації є кріоконсервовані ембріони in vitro, незалежно від наявності генетичного зв'язку з пацієнтами, які дають згоду на донорство. Суб'єктний склад правочину донації ембріонів залежить від анонімності чи неанонімності донорства. Якщо донація є анонімною, то сторонами правочину є донор та заклад охорони здоров’я. У разі неанонімної адресної донації сторонами правочину є донор та реципієнт, а заклад охорони здоров'я виконує виключно посередницькі функції, не набуваючи права власності на донорські ембріони. Якщо донорами є подружжя або чоловік і жінка, що не перебувають у зареєстрованому шлюбі, то донорство ембріонів здійснюється за їхньою взаємною спільною згодою. При цьому згода на донацію ембріонів може бути відкликана до моменту імплантації реципієнту за умови компенсації витрат на зберігання ембріонів у кріобанку. 3 огляду на правову природу донації ембріонів як безоплатного надання донорами свого біологічного матеріалу 3 метою використання для лікування безпліддя інших пацієнтів програм запліднення in vitro, що близька до правової конструкції пожертви, видається, що виплата донорам грошової компенсації за донорські ембріони буде суперечити нормам законодавства.

\section{Список використаних джерел:}

1. Гребенникова К. В. Реализация модели презумпции согласия на донорства в Королевстве Бельгии. Современные наукоемкие технологии. 2013. № 6. C. 141-142.

2. Пташник I. Р. Цивільно-правове регулювання трансплантації в Україні : дис. ... канд. юрид. наук : 12.00 .03 . Київ, 2016. $211 \mathrm{c}$.

3. Брюховецька М. С. Цивільно-правове регулювання посмертного донорства в Україні : дис. ... канд. юрид. наук : 12.00.03. Київ, 2017. 230 с. 
4. Члевик О.В. правові процедури як засоби гарантування свободи. Проблеми законності. 2015. Вип. 129. С. 68-75.

5. Євсєєв О. П. Процедури в конституційному праві України : монографія. Харків : ФІНН, 2010. $201 \mathrm{c}$.

6. Агарков М. М. Избранные труды по гражданскому праву : в 2 т. Москва : ЦентрЮрИнфо Р, 2002. T. $1.452 \mathrm{c}$

7. Петрушко М.П. Сучасний стан проблеми кріоконсервування репродуктивних клітин та ембріонів людини. Вісник Національної академіі наук Украӥни. 2017. № 7. С. 44-53.

8. Ільющенкова К. О. Право на донорство в цивільному праві України : дис. ... канд. юрид. наук : 12.00.03. Київ, 2018. 273 с.

9. Шабанова А. С. Правовое положение донорского репродуктивного материала. Matters of Russian and International Law. 2019. Vol. 9. Is. 7A. C. 82-90

10. Дружинина Ю. Ф. Правовой режим эмбриона in vitro. Журнал российского права. 2017. № 12. C. 134 .

\section{Hanna Krushelnytska. Civil law aspects of donation of in vitro human embryos}

The article examines the civil legal aspects of embryo donation, clarifies the content of the concept of donation and its relationship with the concept of donation. It is determined that from the point of view of civil law, the donation of embryos in vitro is a transaction aimed at terminating the donors' ownership of their embryos and the emergence of ownership of them in other subjects in the field of artificial reproduction. It is noted that only cryopreserved embryos can be the subject of embryo donation, regardless of the presence or absence of a genetic link with donors. Based on a comprehensive analysis of the provisions of the legislation, the parties to the embryo donation transaction are determined. In particular, it is determined that the obligatory subject of donation is the donor. In this regard, it is being investigated which persons can be embryo donors. An understanding of the concept of "patients of an in vitro fertilization program" is provided. The conditions under which patients treated with assisted reproductive technologies can consent to embryo donation are analyzed. Depending on the type of donation (anonymous or non-anonymous), the author determines the second side of the transaction under study: a healthcare institution with anonymous donation and directly recipients with anonymous targeted donation. The article also discusses the possibility of withdrawing voluntary informed consent to the donation of embryos, as a result of which the author comes to the conclusion that such a withdrawal before the embryo implantation does not contradict the current legislation, while it is proposed to oblige donors to reimburse the other party for the costs of storing donor embryos in a cryobank. In addition, the peculiarities of posthumous donation of embryos in vitro are being investigated, if their owners have not made an appropriate order in case of death. In particular, the author concludes that the ability to dispose of cryopreserved embryos after the death of the patients to whom they belonged depends on the presence or absence of a genetic link with them. The article also analyzes the possibility of paying monetary compensation to embryo donors, taking into account the legal nature of donation.

Key words: assisted reproductive technologies, in vitro embryos, biomaterials, donation, donors of reproductive cells. 